\section{Changing Relations between High Castes and Tamang in Melamchi Valley}

Binod Pokharel

\section{Abstracts}

This paper is about the processes of transformation of social relations between high caste groups and Tamang in Melamchi Valley for the period of 1980-2010. Development interventions made by government of Nepal and (I) NGOs, a decade long undergoing Melamchi Water Supply Project and labor migration are major factors for ongoing changes in the study area. Spread of literacy classes and primary education, availability of credit institutions, introduction of modern farming, road networks, seasonal out migration from the area, etc. primarily define new relations among the groups. Borrowing and lending money were one of the basis of high caste and Tamang relation in past. The latter was regarded as borrower loan from first one. Before 1980s, money and agriculture commodities were controlled by few rich and high castes people. Cash income from various sources made enable the Tamang to stand on an equal footing with high caste people. Open political economy and liberal policy for issuing pass port in 1990s and after that encourage the people to diversify the destination of seasonal migration from India to Gulf countries and East Asia. Various processes of socio-economic and political changes led to local peoples to seek their position and identity in the changing context. Discourse of Tamang, high castes and Dalit entered into the Valley along with the development resources of (I)NGO and political movements of the country. This made possible to Tamang and other disadvantage groups to define and redefine their ethnic identity.

Keywords: High castes, Tamang, credit facilities, subsistence farming, identity construction, money lending, wage labor

\section{Introduction}

This paper gives a description in a few of the changes which have come in the past two decades in relation to high castes (Brahmins and Chhetri) and Tamang in the Melamchi Valley of Sindhupalchok district. Various reasons such as long term community development programs, access to motorable road, ongoing mega Melamchi Water Supply Project, changes in agrarian structure of the village, etc. have shaped and reshaped the pattern of interactions and interrelations between these groups. This article also demonstrates that how external development resources and national political movements reconstruct the Tamang identity in local level.

\section{Understanding Social Change in Nepal}

There are different accounts of social change and development in Nepal. Previous empirical studies on change and development in Nepal have focused on varied areas applying various perspectives. We can broadly classify such accounts into two categories. Scholar such as Blaikie et al.(1980); Mishra (1987); Bista (1991); Macfarlane (1976); Shrestha (1998); Ahearn (2004); Litchy (2005), examined social change in terms of processes and implications of development and modernization in social, cultural and economic aspects of Nepalese people. Few scholars such as Caplan (1970), Rankin (2004) and Caplan (1972) observed the change in term of caste and ethnicity.

The general tendency of the previous works (See Blaikie et al, 2001, Seddon, 1979, Mishra 1997) in Nepal is to examine the problem of nation building, development and underdevelopment in relation to world capitalism. They most often to examine empirically the development process that affect people. For example, Blaikie et al.(2001:302) demonstrate that how roads facilitated the penetration by Indian merchant capital at the expense of Nepalese capital, and by Indian factory-produced products at the expense of local artisan manufactures, often produced and exchanged within the bista (Patron-client relation) system. 


\section{Binod Pokharel}

Bista (1991) and Shrestha (1998) sought to find out the causes of underdevelopment and nation building in Nepal by focusing their attention on internal and external factors that hinder development. Bista considers that the conflicting value systems prevalent in the development discourse in Nepal. For him, Brahmanism and fatalistic attitudes are solely responsible for the underdevelopment of the country. However, Bista's work short falls of providing solid conceptual grounds that take into account the cases of development, change and social transformation in contemporary Nepal. Unlike to Bista (1991), Shreatha (1998:59) saw underdevelopment in Nepal due to adoption of Western Development Models. For him, everything from poverty, corruption, prostitution, and deepening disparity and antagonism between classes is a symptom of cultural and spiritual deterioration of Nepali society brought forth by development. However, other empirical finding such as Fujikura (2004) contests with Shrestha's finding. Fujikura points out that development is not only nation building but it are a desire of individual improvement and awareness. The proliferating discourses about awareness and consciousness in contemporary Nepal, according to Fujikura, are implicated in the changing possibilities of being and acting brought forth by the often disjunctive and contradictory effects of the projects of modernization (Fujikura, 2004: 331).

Scholars such as Ahearn (2004) and Fujikura (2004) observe social transformation in Nepal through the examination of policy and practice of pedagogy. Ahearn investigates how villagers have applied their literacy skills to the new courtship practice of love letter writing in Junigau of Palpa district. She discusses the implication of the emergence of love letter correspondences for social relations in Nepal and trace out the broader ramifications for conceptions of agency, literacy, gender, love, and social change. She contends that the transition under way in Junigau represents a shift away from arranged and capture marriage toward marriages facilitated by love letters and how villagers conceived of their own ability to act and attribute responsibility for events - development with potential ramifications that extends far beyond the realm of marriage and well past the Himalayas ( Ahearn, 2004: 7).
Some of the anthropologists (Caplan 1970; Caplan 1972; and Rankin 2004) have shown social, cultural and economic changes in terms of caste and ethnicity. Caplan (1970:189) focuses on Brahmin-Limbu relation in terms of land and social change. According to him, Limbu and Brahmin relation are characterized by two opposed tendencies: interdependence and cleavage. According to him, the cleavage between the Limbus and their Hindu neighbors arises not only or primarily out of racial and cultural differences between them. Rather, this aspect of their relationship can best be understood in the context of a confrontation over land. Interdependence, according to him, derives from the separate but complementary roles they play in the agricultural economy as a result of the distinct type of access to land which each enjoy. Caplan (1972) demonstrates the social relation between Brahmins and cobblers in a Hindu village in the hills of western Nepal. She focuses that how economic, political and cultural links between two groups has been shifted since 1951 . She shows that change was the result of a chronic shortage of cash, needed for paying taxes and purchasing certain essential commodities which had an imported. According to her, Brahmins were wealthy and powerful and lent money to cobblers and took land on mortgage in return. Much of the land which was sold and mortgaged belonged to untouchables, who had only limited access to cash. Cobblers were heavily dependent upon the Brahmins to meet the ends.

Liechty and Rankin analyzed economic dimensions to understand social process in Nepal. Rankin (2004:1) explores how the value ascribed to social prestige relates to economic opportunity. She says that "market led development will not necessarily expand opportunities as the ideology of the free market would have it; rather it may deepen existing injustice and inequalities". She investigates "specially caste and gender ideologies that underpin the Newar cultural economy in the Sankhu, stressing the disadvantages faced by low caste and women in the accumulation of symbolic and material capital"(Rankin, 2004: 72).

Litechty (2008) sketches growth and development of middle class in Kathmandu. According to him, middle class social currency of consumer goods and images serves to deflect attention away from 
an even more basic form of currency- cash without which participation in a commercialized prestige economy is impossible. He describes the lived experience of middle classness and shows how class is actually produced and reproduced in everyday practice. In order to understand new middle class cultural practices, he examines cinema and video viewing, popular music, film magazines, local fashion systems and advertising. According to his conclusion, much of middle class practice is about the transformation of cash into social currency, the translation of market privilege into cultural privilege, and deployment of a limited resource to create a limiting form of cultural life. He further notes, middle class privilege is always depoliticized, its economic advantage naturalized, behind cultural screens of status, life style, honor, education, achievement and so on (Litechty, 2008: 253).

Despite the growing number of social change and development literatures in Nepal, few studies have examined interface between caste and ethnic groups. Many of them failed to see how development interventions, economic process and political movements shape and reshape the social relations among the caste and ethnic groups in Nepal.

\section{Research Area: Migration and Change}

The fourteen VDCs of western Sindhupalchok are known as Melamchi Valley. Geographically, the Valley can be divided into three regions such as low land, middle hills and high land. These geographical areas correspond generally to the three main ethnic/caste groups in the Melamchi Valley: the low land dwelling Hindus (Brahmin/Chhetris, other Castes and Untouchables), the Tamang in the middle hills and the Yolmo in the high land of the Valley. There are some smaller ethnic minority groups in the Melamchi Valley: Newar, Gurung, Sanyesi, Bhujel, Danuwar, Gurung, Magar and Majhi.

The Tamang are the most populous group in Melamchi Valley (38.54\%) as well as in Sindhupalchok district (32\%). According to local legends, the Tamang were the first settlers of the region. They are found in all fourteen VDCs of the Melamchi Valley with their higher concentration in Mahankal VDC, the present study area, where they comprise $66 \%$ of the total population. Most of the Tamang villages are placed in the middle part of the VDC. They reside close to the Yolmo populations in the upper parts and Brahmin/Chhetris Hindus and Dalits in the lower parts. They live across the terraces that they cultivate.

Hindu groups, such as the Brahmins and Chhetris, live in mostly the western part of Sindhupalchok of Melamchi Valley; yet they predominantly inhabit the lower Indrawati and Melamchi Khola. In the northern regions, they only account for less than $10 \%$ of the population (Graner, 1997:132). Jaisi Brahmin and Chhetri are the two groups of Brahmin/Chhetris in the study area. They are numerically the largest population in the sample villages and second largest group in the VDC.

The caste/ethnic mix of the area can be attributed to in-migrations in the past from different areas around the Melamchi Valley. Most of the migration to the area took place around nineteenth century. The other groups, Brahmins, Chhetris, Newars, Danuwars, Magars and Gurungs, came down to the Valley in the late eighteen to early nineteenth centuries (Graner, 1997; Pokharel, 2010). The Yolmos of the highland migrated from Tibet over more than 250 years ago (Bishop, 1998).

The migration of Brahmin/Chhetri people to the region was subsidized by the state. In the early eighteenth and nineteenth centuries, the states assigned the land to the Brahmin/Chhetris people in the form of birta, jagir and guthi land tenures. Before 1951, it was common in Nepal to assign the land to Brahmin/Chhetri people to insure a stable and secure income through which rulers could extract taxes without tension (Regmi, 1976). According to Graner, "land grants were an important vehicle of settlement history and increasingly brought Brahmin and Chhetri into the Melamchi Valley" (Graner, 1997: 132). The Newar of Melamchi Valley migrated from Sankhu and Banepa as economic migrants in early $20^{\text {th }}$ century. Most of the Newar settlements could be found along the main trade route to Tibet.

In the past, land granting was not only limited to high castes Hindu. Guthi land (religious land) used to endow to all caste and ethnic groups before 1950. Yolmo of the upper part of Melamchi 
enjoyed such state land granting system in the name of temple/Gumpa. Clarke (1980) demonstrates that state policy of land-grants gave an institutionalized permanence to temple sites in Helambu, and this was the seed of local development which recast Tibetan Buddhist culture in the idiom of small-scale community. New elites emerged among the Yolmo (Lama People) due to land granting policy for religious temples. Lama people not only enjoyed the economic surplus from land, but also political and spiritual authority which was concentrated in the hand of one people: the Lama people of Helambu (Clarke, 1980: 322). Still, many pieces of khet land lying in the low land are in the name of Gumpas.

It is said that Tamang occupied the whole area of this region. Later they sold the low land to new comers, the Brahmin/Chhetris. During the Rana Regime, the land tax of the khet land was high and production was low, and they sold their khet land to the Brahmins/Chhetri people. It might be a strategy for them to escape from government taxation policies or it was a kind of resistance to state land tax policies in the past. Religiously, all Gumpas or Ghangs are located at the hill top of the village. Therefore, it is quite natural to live at hill top for daily worshiping and maintaining of Gumpas.

\section{Education: Demand of Time}

Literacy practices in the study area helped to shift high caste and Tamang relation. In the past, Tamang were relied on high caste for reading and writing letters, notice and debt vouchers. Before 1980s the literacy rate was very low among the Tamang. There were no any schools in Tamang villages. Few of them used to come down to low land for education.

The overall literacy of the study villages is 74.5 percent. This figure is higher than the district (31\%) and national level literacy rate (54.1\%). The literacy rate amongst Brahmin/Chhetris is nearly 85 percent and is followed by Tamangs (68.4\%). The possible reason for their high literacy rate is that opening of schools and many literacy classes were run by Action Aid in the villages of Mahankal in the late 1980s and early 1990s. Compulsory primary education programs, intervention of development organizations for literacy, and the need for basic literacy to work as urban wage laborers also helped to increase the literacy status of the people over the last decade. Some of the Tamang boys are taxi drivers in Kathmandu and New Delhi. According to a respondent, a person needs five grade passed certificate to be a driver in New Delhi. Because of this provision Tamang boys join to school up to five class. A local teacher reports, "some Tamang boys, who were dropped out from school without completing five class earlier, visit to school to make five class passed certificate. We also make a certificate as per their demands taking some fees". This indicates that more Tamang children join the school to prepare urban job and five pass certificate facilitate them joining driving type of labor works in urban town.

\section{Change in Agriculture: Land and Productivity}

Khet and bari are two major categories of cultivated land in the study area. Khet has two sub-categories; khola khet (irrigated khet land lying on the bank of Melamchi river) and Pakha Khet (rain fed khet land located in upland). Khet land located in the lowland has both economic and social value. According to field survey, a large segment of the households (67\%) has khet land in the range of 1-6 ropani while about six percent has land 6-9 ropani in total. Approximately, ten percent of the households have more than ten ropani khet land. All of the Brahmins/Chhetri groups own khet land while 23 percent Tamang have no khet land. This ownership of land is low compared to Nepal as a whole ( 0.95 hectare per household). The majority of khet land holders from Tamang occupy pakha khet where winter paddy crops and wheat are grown. All households occupy small pieces of land in the village. Of the khet holders, 22 houses had land in the range of 1-3 ropani. In khola khets three crops can be grown annually, while only two crops can be grown on pakha khets. Maize and millet are the major crops in bari land.

The average land holding size of Brahmin/Chhetris is 6.61 ropani (0.33 ha) for khet and 9.22 ropanis (0.46 ha) for bari, which is lower than the average Nepali landholding size (0.95 ha). However, they own more land in comparison to Tamangs and the 


\section{4 | Binod Pokharel}

khet land owned by them is very fertile and they can grow three crops annually, which is not on Tamang lands. They own more than 90 percent of khet land lying in the lowland where irrigation facilities are available throughout the year. They grow three crops; i.e. paddy, wheat and another paddy in a year.

Before 1980s, agricultural technology was simple with low productivity in the Melamchi Valley. During that time all kind of people used to experience food shortage and famine in each year. With the state intervention along with Action Aid Nepal after 1980s, agricultural practices of the study area have changed and productivity of the land increased significantly in low land. Introduction of irrigation canal and other inputs to khet lands made possible three times harvest in a year. Buddhi Krishna Lamichhane of Sera says "we have the same landholding size since last twenty years. In our father's time our production could just meet the food demand for six months. Now we have surplus food due to the application of chemical fertilizer and multiple yearly harvests.”

New agricultural practice has hardly changed the plight of Tamang people. A respondent views that "agricultural production in Tamang land has not changed over the year. Whatever were done by development interventions in the area of agriculture is suitable for the lowland (Brahmin/Chettri villages). Present and past development practices in agriculture are related to irrigation and paddy production. Both of these are absent in Tamang villages".

In the past, Tamang were largely dependent on high castes for borrowing and buying paddy and they seasonally worked as agricultural labor in the field of Brahmin and Chhetris. Sometimes they used to buy it from high caste households. Now situation has changed. New labor market opportunities that are availed inside and outside the village, expansion of market in the Melamchi Valley, etc. have gradually declined the Tamang dependency over high caste groups. Respondents view that "we used to go high caste house if we would need of rice but now new incomes (mostly from local wage labor and business in Melamchi Project and seasonal migration and wage labor in various part of Nepal and India including gulf countries) enable us to buy rice and other commodities in local market". Importantly, social and cultural value embedded with rice declined with the growth of market and labor opportunities in local level. In the past, rice producers, both in cultural and economic sense, had higher status than other commodity producers and cash earner. According to field report, there were few households who produced surplus paddy and they had a monopoly on distribution of it. Remembering the past event, a Tamang respondent says "we used to visit to food surplus household to buy or borrow rice and the sellers asked us to do some works (such splitting firewood, digging land, and collecting fodder) before selling or lending their rice.

Respondents say "we used to go seeking job at the house of rich and high caste households. Laborers were paid in kinds (mainly maize or millet). Now situation has changed they come to our house to seek agriculture labor". Youth of the study area are reluctant to do as an agricultural labor due to uncertainty of job and availability of other kinds of wage labors (collecting boulders and stones, road construction, upload and unload goods from vehicle, etc.). Because of scarcity of agricultural labors the land owners have to pay more to hire agricultural labors (khetala) than other type of wage labor works.

It seems that high caste people largely depend upon Tamang for tilling their land. They gave up keeping oxen and cattle due to restriction on grazing in community forestry and lack of manpower to look after the cattle. In the past, livestock rearing was a duty of children but now they attend school and there is no one to look after the cattle. People started to keep few improved varieties of cattle and buffalo with stall fed manner targeting to milk sale. However, Tamang still keep a pair of oxen. The oxen are not only used to till their own land but also the land of Brahmin/Chhetri people during the paddy planting season. The wages for ploughing in the fields in 1990 was 100 rupees for a day's work. Now the wages are about 350 rupees. The Brahmin/Chhetri people gave up keeping ox. It is cheaper to hire oxen to plough land than keeping them. A respondent commented that a pair of bullocks needs more fodder than a single buffalo.

\section{Changes on Local Wage Labor}

Fürer-Haimendorf (1966) observes that "Tamang furnish the greater part of the porter-force required for the movement of trade 
goods along the mountainous paths”. However, in the Melamchi Valley, the opportunities of long distance portering have tremendously decreased due to opening up of the road. Short distance portering is available from road head to village. The working force come to the road construction area at Gyalthum, Sindhukhola and Timbu where they carry stones, break stones and collect stones as well. A few of them upload and download shop keepers' goods at market centers. A higher percentage of Tamangs were involved in skilled and unskilled labor compared to Brahmin/Chhetris in the study area.

The Khelo system was an old age tradition of the Tamang. Khelo is a system of economic transaction where the Tamang used to buy paddy with rich Brahmins and de-husk the paddy into rice with a $d h i k i^{1}$. They would also carry rice to Sankhu and Sundarijal of Kathmandu for sale. When they sold rice in Kathmandu it provided a small profit. At that time, few Brahmin had food surpluses and they had monopoly over the rice trade. In order to buy paddy, Tamang had to fulfill some obligations to rich Brahmin. Generally, they were asked to plough land or split firewood for free. Tamang displaced from the profession with the establishment of the rice mills and the construction of the road in the Melamchi Valley.

The Tamang and Dalit have good masonary, carpentry, wood carving and weaving skills. All of the houses constructed in the low land were made by the Tamangs. Such an opportunity is available for them in the winter season because the construction of new houses and repair of old houses is done in the winter season. This job opportunity has increased over the last five years when the low land people received compensation of land from the Melamchi Water Supply Project. Most of the compensation holders invested their money to build the new houses. Generally, Tamangs took the work on a contract basis but where the owner had to provide three meals a day. The method of payment was cash. Providing food to khetala or other type of workers is common in the study area. Such

${ }^{1}$ A wooden machine (with a pole with a pestle which is raised and descended sharply into a hole of the stone on the ground) for husking rice. a practice helped to feed household workers who could save foodstuff at home. Unskilled jobs include collecting and breaking stones, preparing mud for wall construction, leveling the site for building houses, carrying timber, carrying loads from the road side to villages and loading/unloading goods from vehicles.

\subsection{Wage Labor: From India to Gulf Country}

Seasonal migration in India is an old age tradition of people in Melamchi Valley. The old people of the study area had varied experiences while they were working in India. Almost all old people have been in India at least once in their life. In the beginning, they used to go along with the Yolmo. Yolmo have a long tradition of circular migration in different states of India (Bishop, 1998). In the early 1980s, many households of study area migrated to India leaving the old age people and younger children at home because of widespread famine and debt. To fulfill the demand of food and cash they used to go to India for seasonal migration. Some of them used to live in India and back home if there was enough manpower to look after the farm and livestock. Most of them worked in Himanchal Pradesh, India for many years. Except few rich Lamichhane Brahmin, all people of Sera and Maramche had experienced of seasonal labor migration to India.

In the sample households, 13 persons were working in India. Among them 7 were from Dalit followed by Tamang (5 people) and Brahmin/Chhetris (one person). All of the Tamang migrants were doing driving jobs in Gurgaon and Delhi while Dalits were in Himanchal Pradesh, Shillong and Laddkha. Earlier seasonal migration of people was confined to coal mine in Shillong. Later destinations diversified to other parts of India, basically Himanchal Pradesh. Generally, the seasonal migrants come back home at least one time in a year with 10-30 thousands Indian rupees. They invest this money by buying food stuffs, clothes, goats and buffalos. Some of them used their money to repair or reconstruct houses and animal sheds. A few of them lend money to relatives with 20-25 percent interest rate.

The destination of seasonal migration has changed from India to Gulf countries and East Asia after the political changes in Nepal after 1990s. In the sample, there were five persons who were 


\section{8 | Binod Pokharel}

currently working in Malaysia. It is estimated that there were 25-30 people from Brahmin/Chhetri people in Malaysia and other Gulf countries. Generally, they worked in Malaysia and earned approximately 500,000 rupees in total three years tenure. This money is basically used to pay back their loan on travel, land purchases in the village and outside of the village and the construction of new houses in the village.

\section{Girl Trafficking: Destination Shift}

Haimendorf (1966) wrote that Tamangs were economically important as hewers of wood and carriers of loads but their social position was low. They normally entered Brahmin/Chhetris' and Newars' houses in no other capacity than as servants and farm hands. Though there were few cases of Tamang girls living with Chhetri or Newar households as a second wife. This has indirectly led to further girl trafficking problems in the area. Girl trafficking, rampant in the region today, is believed to have originated in the past due to the practice of providing young Tamang girls as concubines to the Rana courts in Kathmandu.

Bishop has given a brief account of Tamang migration and girl trafficking in India. She reports that "many Tamang of Melamchi Valley experience months of hunger each year and migration is an obvious way out: Men leave for wage labor and women for prostitution. The stories of deceit, abandonment, abuse, and being sold and resold often don't return to the women's home villages, since girls may disappear forever; so many young girls remain susceptible (1998:146). However, a few recently publicized cases and the anti-sex trafficking campaigns of the government and other NGOs have made many people aware of the realities of sex trafficking.

As reported in the field, 20 girls of Tamang from Maramche were in Kuwait. In the past, most of the girl trafficking was to different cities of India. Recently, the destination has changed from India to Gulf countries. In the recent years, the government adopted a liberal policy for issuing passports. This policy allows people of 18 years and above to hold a passport. There is a general tendency in the study area to hike age of person of below 18 age groups to get passport. As the researcher observed in Mahankal VDC office, a large number of Tamang girls come to get a recommendation from the VDC for passport. Sometimes the researcher noticed that the VDC secretary had been pressured to give a recommendation letter to ineligible candidates as well. The VDC secretary said "Ten years ago I made a birth certificate for this Tamang girl. According to office records, now she is thirteen years old. Now her father asked me to cancel the earlier birth registration form so that she would be eligible to get passport." Those who do not have a registered birth certificate, have easy time manipulating their age. In Nepal, only parents are the authentic person to verify the age of their children. The VDC authority should accept their parents' report; whether it is true or false.

\section{Traditional Money Lending to Credit Facilities}

Before 1980s both Tamang and high caste villages used to experience food deficit and famine couple of months of a year. Food deficit was more acute in Tamang Villages than in low land of the high caste villages. Few of the rich households of the low land had food surplus during those days. The study area was cashpoor region. Cereal commodities and cash were controlled by few people. The poor households including Tamang were largely depending on rich household for food and loan. Loans were taken with high interest rate i.e. 36 percent per annum. The borrower had obligation to work off the field of money lenders. There were also many cases of confiscation of their land and other forms of collateral. Whatever they produced from the land, they had to use to pay their loan and nothing would be left for their family. Loan was generally taken for food, sickness and mortuary ritual. Ghewa is a more expensive death ritual. Sometimes they sought loan to arrange court fees and to release own persons from the prison.

Saving Credit Group (SCG) was established by Action Aid Nepal (AAN) in mid 1980s. SCG intervention reduced the rate of interest compared to the past. Another significant point noted during the fieldwork was the availability of credit at the local level. SCGs had played a significant role in reducing the exclusive dependency on local moneylenders and had increased the cohesiveness of group members. People saw SGC as more progressive than traditional 
institutions. Development processes of AAN, non-Formal Education classes, exposure visits, trainings and meetings, presented that traditional money lending was oppressive and were regressive institutions used to extort more interest from people. Many stories of exploitation by local money lenders came out through the empowerment process. SCG became the centre for money lending and borrowing during the project period. The implication of SGC was access to poor people in cash economy. Of course, these funds made local people stronger and reduced their reliance on local moneylenders, but they could not be a threshold for enterprise development, which was expected from the project.

With the formation of saving credit groups AAN could provide seed grants for the groups, narrowing room for traditional moneylenders. The notion of personal savings was a novel experience for many rural poor because of their generalized poverty and their lower position in village society. This made possible to find small loan from own groups. Respondents reports "self-help group could not change their life in substantial ways but now we should not have depend on money lenders to tiny expenses". With the growth of outside labor migration, development activities in the villages and commercialization of dairy production have increased the cash flow in the valley.

\section{From Subsistence Farming to Commercial Market}

In 1999, there were a handful of shops and a high school in Mahankal VDC. There were three tea stalls and one hotel with lodge in Patichaur. The growth of study area since that date has been dramatic. In 1999, the local fruits, bananas and jackfruits, were distributed among kin but are now sold in the market. Unlike any other part of Melamchi Valley, the business sector of Mahankal is largely controlled by local Brahmin/Chhetri people. Of the total business centers, 20 are owned by Brahmin/Chhetris and 13 by Tamangs and Yolmos.

Grocery, cosmetics, stationery, tea shops, medical stores, ready made goods, rice mills, and ghattas (water mill) are the major types of the business. All business houses were established along the roadside. The shopkeepers bring the goods from Banepa, Khasa
(Tibet), the Terai and Kathmandu. They also buy and sell local products such as paddy and other cereal crops.

Most of the dealings are held in credit (udharo). Outstanding credit is dependent on the type of items. For example, chemical fertilizer is generally sold on credit and farmers pay back the loan after harvesting the crops. Some of the farmers took fertilizer and pay in paddy instead of cash. The farmers pay the credit of dhuto (fine husk used as animal fodder) on a bi-monthly basis when the payment of milk is made by Nepal Dairy Development Corporation. The business of animal feed and veterinary services has increased. Milk selling business generates some jobs at the local level. Milk collectors, loaders, fat testers and account keepers positions are also created because of this business.

\section{From Assimilation to Identity Construction}

There is considerable influence from Hinduism on Tamang culture. They celebrate all Hindu festivals and worship the Palchokbhagawati (Hindu goddess) by sacrificing five beasts known as panchabali (male goats, hens, male buffalos, pigeons and eggs) in the name of goddesses and gods in order to fulfill their wishes. Gosaikunda, a holy lake, is a common pilgrimage site for both Hindus and Buddhists in this area. The education system and migration lead Tamangs to assimilate into Hindu culture. This included the introduction of Nepali language because the Hindu practices of younger generations of Tamang did not prefer crosscousin marriages since they are not the norm in Hindu culture. In school level textbooks, there are many elaborations of Hindu culture that have also influenced Tamang children. Despite this influence, it has had little effect on some Tamang rituals such as death, birth, etc. The Tamang of villages are quite familiar with Hindu festivals more than their traditional festivals, Lhosar, Nhara, and Dukpa. Some of the younger generations of Tamang do not know that Lhosar is their main festival. The magnitude of assimilation with Hinduism is not the same in all Tamang settlements. The Tamangs who live near the Hindu households are more assimilated and displayed Hindu values more than the Tamang of remote villages. 
After 1990s political change of the country, many political parties incorporate to Tamang to party politics. Many VDC level positions were given to them. Development programs i.e. Action Aid community development program and minority development plan of Melamchi Water Supply Project at local level help to increase the power of minority voices. Earlier Tamang identity was an expression of their cultural, economic and political deterioration. After the political movement 2006/2007 is not limited to political and economic deterioration but they sought to find their cultural identity by abandoning to celebrate the Hindu festivals such as Dasain and Tiwar.

In the past, most of the development works were done in low land of high case villages. Still this trend has not significantly changed. However, they can contest and assert their demand towards concerned development agencies. All of development activities were related to irrigation canal and school building they were held in low land. A respondent said "many development activities are held in Brahmin/Chettri villages. We generally got a foot trail maintenance project from the VDC and other development agencies because that might get washed away in the monsoon".

Discourse of Tamang, Dalit and high castes entered Melamchi Valley along with development intervention. Action Aid community development (19882-2000) dichotomized village societies in terms of caste, ethnicity and spatial locations (Pokharel, 2010). Many of them started to see themselves economically poor and disadvantage groups of the Melamchi Valley. Development discourses (literacy practices, group formation and participatory activities) were the earlier sources of ethnic identity. Maoist people war (1996-2006) and political movement of 2006 further shaped the Tamang identity in the study area. It seems that NGO/INGO resources and legitimacy helped create recognition of the Tamang's identity in the village and helped reproduce ethnic relations to some extent. After the political change of the 1990s, politicians and political parties would not offend Tamang or other disadvantaged groups directly due the importance of their vote. Tamang did not receive anything remarkable from development projects but it made them aware and they understood the changing demands of time (Fujikura, 2004).
The multiparty system and development interventions opened up opportunities for Tamangs to ally with other dominant Brahmin/Chhetris, partly because it served to compel Brahmin/Chhetri politicians to cater to the plight of Tamangs and for their votes (Masaki, 2004). Development interventions enabled Dalits and Tamangs to challenge the dominant practices of development and were adopted by local elites and agents of development. It also facilitated locals' resistance and helped them reevaluate their identity. In the past, they could not ask whatever done by developers or elite people. Still they could not receive any more development program than the low land people Brahmin/Chhetris. They could ask developers about discriminatory practices against the disadvantaged groups.

\section{Conclusion}

The above discussion shows that there have been a number of changes in Melamchi Valley. Discussion suggests that after 1980s many changes are seen in economic and political changes in the Melamchi Valley. Relations between Tamang and high caste are defined or redefined over the decades due to historical processes of change, various development interventions in the valley, transformation of rural economy, globalization of local labor force, political movement of the country, etc. Three things- community development programs, road access and labor opportunities at local level, were major factors to reshape the high caste and Tamang relations. Cash income enables the Tamang help to stand on an equal footing. Open political system and liberal policy for issuing pass port encourage the people for foreign job. Opportunities of wage labor both inside and outside of the country and credit facilities at the village level significantly decreased economic dependency of Tamang over rich Brahmin and Chhetri.

Rankin (2004) suggests that market creates different opportunities and constraints for differently positioned social groups, as well as shaping the parameters of labor markets and commodity circulation (p.186). Process of community development and other general development in the Melamchi Valley have been diversified the local labor markets. A shift in occupational structures (from 
subsistence farming to wage earning) is one of the major factors for the transformation of high castes and Tamang relations.

Political change, state policies and socio-cultural context play an important role for the reformation of ethnic identity. Open political system opens the space for ethnic identity. Tamang used to celebrate Hindu festivals such as Dasain. They started to see some problem with earlier assimilation in the changing context of the country.

\section{${ }^{\mathrm{i}}$ Research Methods and Research Site}

This article is based on my empirical research work carried out in Mahankal VDC, Melamchi Valley, Sindhupalchok district during 2006 and 2007 where I spent ten months doing ethnographic fieldwork for my PhD research. Mahankal VDC is the central part of Melamchi Valley and represents all of the socio-cultural and geographical uniqueness of Melamchi Valley. Data were collected in five villages (Patichaur, Sera, Gyalthum, Gangetar and Maramche) of Mahankal VDC. The main tools used in the study were participant observation, informal and formal interviews, household survey and analysis of archival records.

ii This article is based on my $\mathrm{PhD}$ research that was funded by European Union Asia-Link Project: "The (micro) Politics of Democratization: European-South Asian Exchanges on Governance, Conflict and Civic Action” (MIDEA). In particular, I am also grateful to Prof. Joanna Pfaff-Czarnecka, Prof. David Gellner for their generous support and guidance while doing my $\mathrm{PhD}$ research on behalf of MIDEA project. I am grateful to my dissertation supervisor Prof. Dilli Ram Dahal including Prof Ram Bahadur Chhetri, Prof Chaitnya Misra and Dr. Laya Upreti for their comments on a subsequent draft.

\section{Reference}

Ahearn, L. M. (2004). Invitation to love: Literacy, Love letters, and Social Change in Nepal. Delhi: Adarsha Books.

Bista, D. B. (1991). Fatalism and development: Nepal's Struggle for Modernization. India: Orient Longman Ltd.

Blaikie, P.M.; Cameron J. \& Seddon, D. (2001). Nepal in Crisis:
Growth and Stagnation at the Periphery. Delhi: Adroit Publishers.

Caplan, P. A. (1972). Priest and Cobblers. London: Chandler Publishing Company.

Clarke, G. E. (1980). The Temple and Kingship among a Sanatst People of the Himalaya. PhD. Dissertation, the University of Oxford.

Fujikura, T. (2004). Discourses of Awareness: Development, Social Movements and Practices of Freedom in Nepal. Unpublished Ph.D. Dissertation, Department of Anthropology, Chicago, Illinois (USA).

Fürer-Haimendorf, C. V. (Ed.) (1966). Caste and Kin in Nepal, India and Ceylon: Anthropological Studies in HinduBuddhist Contact Zones. Bombay: Asia Publishing House.

Graner, E. (1997). The Political Ecology of Community Forestry in Nepal. Saarbrücken/Germany.

Liechty, M. (2003). Suitably Modern: Making Middle Class Culture in Kathmandu. New Jersey: Princeton University Press.

Masaki, K. (2004). The Transformative Unfolding of Tyrannical Participation: the Corvee Tradition and Ongoing Local Politics in Western Nepal. In Samuel Hickey \& Giles Mohan (Eds.), Participation: From tyranny to Transformation? Exploring new Approaches to Participation in Development (pp.125-139). London and New York: Zed Books.

Pokharel, B. (2010). Anthropology of Development: Policies and Practices of Community Development in Melamchi Valley. Unpublished PhD Dissertation, Tribhuvan University.

Regmi, M. C. (1976). Land Ownership in Nepal. Berkeley: University of California.

Shrestha, N. R. (1999). In the Name of the Development: A Reflection on Nepal. Kathmandu: Educational Enterprise. 